\title{
Effects of Urea Infusion on the Uterine Luminal Environment of Dairy Cows
}

\author{
M. L. Rhoads, ${ }^{1, *}$ R. O. Gilbert, ${ }^{2}$ M. C. Lucy, ${ }^{3}$ and W. R. Butler ${ }^{1}$ \\ ${ }^{1}$ Department of Animal Science and \\ ${ }^{2}$ College of Veterinary Medicine, Cornell University, \\ Ithaca, NY 14853 \\ ${ }^{3}$ Department of Animal Science, University of Missouri, \\ Columbia 65211
}

\begin{abstract}
Previous research indicates that high plasma urea nitrogen (PUN) concentrations are associated with decreased fertility in lactating dairy cows. The objective of this study was to monitor changes in the uterine environment during acute elevation of PUN. Lactating dairy cows $(n=8)$ were infused with saline or urea $(0.01$ $\mathrm{g}$ of urea/h per $\mathrm{kg}$ of body weight) through jugular vein catheters on d 7 after estrus. After $24 \mathrm{~h}$, cows were switched to the opposite treatment for a second 24-h infusion period. Blood samples were collected every 2 $\mathrm{h}$, and the $\mathrm{pH}$ within the lumen of the uterine horn ipsilateral to the corpus luteum was recorded every 6 h. At the end of each 24-h infusion period, $30 \mathrm{~mL}$ of sterile saline was flushed into the uterine lumen and immediately retrieved. Mean PUN concentration increased from $16.6 \pm 1.3 \mathrm{mg} / \mathrm{dL}$ during saline infusion to $22.6 \pm 1.3 \mathrm{mg} / \mathrm{dL}$ during urea infusion. Uterine $\mathrm{pH}$ decreased during urea infusion from $7.08 \pm 0.07$ at $6 \mathrm{~h}$ to $6.88 \pm 0.08$ at $18 \mathrm{~h}$, but was unchanged during saline infusion (7.01 \pm 0.08 at $6 \mathrm{~h}$ to $7.06 \pm 0.07$ at $18 \mathrm{~h})$. Protein concentration, $\mathrm{PGF}_{2 \alpha}$, and prostaglandin $\mathrm{E}_{2}$ concentrations in uterine lavage samples were not different between treatments. The results of this study indicate that a short-term increase in PUN can exert direct effects on the uterine environment by decreasing uterine $\mathrm{pH}$.
\end{abstract}

(Key words: urea, uterus, reproduction, dairy cow)

Abbreviation key: $\mathbf{C A}=$ carbonic anhydrase, $\mathbf{P G E}_{\mathbf{2}}=$ prostaglandin $\mathrm{E}_{2}, \mathbf{P U N}=$ plasma urea nitrogen .

\section{INTRODUCTION}

Dairy farmers commonly feed diets that contain high levels of protein to maximize milk production. Feeding

Received November 12, 2003.

Accepted June 5, 2004.

Corresponding author: W. R. Butler; e-mail: wrb2@cornell.edu.

*Present address: Department of Animal Science, University of Missouri, Columbia 65211. excess protein to dairy cows increases blood urea nitrogen concentrations, and high blood urea nitrogen has been linked to low fertility (Blanchard et al., 1990; Canfield et al., 1990; Elrod and Butler, 1993; Ferguson et al., 1993; Butler et al., 1996). Conception rates of lactating dairy cows decreased approximately 20 percentage points when plasma urea nitrogen (PUN) or MUN concentrations exceeded $19 \mathrm{mg} / \mathrm{dL}$ (Butler et al., 1996). Similarly, Ferguson et al. (1988, 1993) reported a decrease in conception rate when serum urea nitrogen concentrations were greater than $20 \mathrm{mg} / \mathrm{dL}$. RajalaSchultz et al. (2001) found that cows with MUN concentrations below $10 \mathrm{mg} / \mathrm{dL}$ were nearly two and a half times more likely to be confirmed pregnant than cows with MUN concentrations above $15.4 \mathrm{mg} / \mathrm{dL}$.

Composition of the uterine luminal fluid in cows fed high protein diets has been examined to elucidate the mechanisms responsible for reduced conception rates. Jordan et al. (1983) found that cows fed a high CP diet had decreased concentrations of $\mathrm{P}, \mathrm{Mg}$, and $\mathrm{K}$ in uterine fluid during the luteal phase, but uterine $\mathrm{P}, \mathrm{Mg}$, and K were similar at estrus. Elrod and Butler (1993) and Elrod et al. (1993) fed diets differing in RDP and RUP content to dairy cows and heifers, resulting in elevated PUN. Uterine luminal $\mathrm{pH}$ was measured on the day of estrus and $7 \mathrm{~d}$ after estrus. Uterine $\mathrm{pH}$ of control and high PUN cattle was similar at estrus. On d 7 after estrus, however, high PUN concentrations were associated with low uterine $\mathrm{pH}$. Uterine $\mathrm{pH}$ on $\mathrm{d} 7$ after estrus is of interest because if the oocyte had been fertilized, the embryo would be within the uterine lumen. Because placentation has not yet occurred, the $\mathrm{d} 7$ embryo is dependent on uterine secretions for survival. Changes in the uterine environment during this period could compromise early development or viability of the embryo.

The results of previous research showed that elevated PUN concentrations caused by feeding high protein diets change the uterine environment of dairy cattle. However, previous studies have not tested the effects of urea separately from other metabolites of protein 
digestion. Therefore, the objective of this experiment was to measure the characteristics of the uterine luminal environment during acute elevation of PUN initiated by intravenous urea infusion.

\section{MATERIALS AND METHODS}

\section{Experimental Study}

Multiparous lactating Holstein dairy cows ( $\mathrm{n}=8 ; 40$ to 100 DIM) were used. Cattle were housed in AAALACaccredited facilities; protocols involving animals were approved by the Institutional Animal Care and Use Committee of Cornell University (Ithaca, NY). Estrous cycles of the cows were synchronized with one injection of GnRH (0.05 mg; Cystorelin, Rhone Merieux, Inc., Athens, GA) followed $7 \mathrm{~d}$ later by an injection of $\mathrm{PGF}_{2 \alpha}$ (25 mg; Lutalyse Sterile Solution, Pharmacia Animal Health, Kalamazoo, MI). Three days after standing estrus was observed, cows were moved to monitor rooms in the Large Animal Research and Teaching Unit. Transrectal ultrasound examination of ovarian follicles was conducted daily from the time of the $\mathrm{PGF}_{2 \alpha}$ injection until ovulation. Both jugular veins of each cow were then catheterized in preparation for treatment and blood sampling.

Cows were fed a TMR for ad libitum consumption (31\% concentrate: $69 \%$ forage). The TMR had a moderate concentration of $\mathrm{CP}(15.2 \%)$ and energy content was formulated for early lactation $\left(1.61 \mathrm{Mcal} \mathrm{NE}_{\mathrm{L}}\right.$ per $\mathrm{kg}$ of DM). Cows were given fresh feed every $6 \mathrm{~h}$ to encourage frequent feed consumption for maintaining a constant amount of endogenous urea production throughout the study. Cows were milked twice daily at 0600 and $1800 \mathrm{~h}$.

Cows were assigned randomly to receive the saline (control; $n=4)$ or urea ( $n=4)$ infusion treatment beginning on $\mathrm{d} 7$ after estrus. For the urea treatment, an initial loading dose of urea (Sigma-Aldrich Company, St. Louis, MO) was administered through the jugular catheters to rapidly elevate circulating concentrations of urea and expedite equilibration of urea in tissue fluids to concentrations that would be maintained by the continuous infusion. The loading dose of urea $(15 \mathrm{mg}$ of urea per $100 \mathrm{~mL}$ of blood volume estimated as $7 \%$ of BW) was dissolved in $100 \mathrm{~mL}$ of saline and was determined from results of a preliminary trial. The infusion dose of urea $(0.01 \mathrm{~g}$ of urea/h per $\mathrm{kg}$ of $\mathrm{BW}$ in saline) immediately followed the loading dose, and was delivered by a syringe pump at a rate of $0.5 \mathrm{~mL} / \mathrm{min}$. Control cows received comparable infusions of sterile saline. After $24 \mathrm{~h}$ of infusion, cows were switched to the opposite treatment, and received loading and infusion doses as described above. The second infusion period lasted $24 \mathrm{~h}$, for a total treatment period of $48 \mathrm{~h}$.
Blood samples were collected from a jugular vein catheter every hour for the first $12 \mathrm{~h}$ of treatment and thereafter collected every $2 \mathrm{~h}$. The blood samples were centrifuged at $1200 \times g$ and the plasma fraction was collected and stored at $-20^{\circ} \mathrm{C}$. Plasma urea nitrogen concentrations were determined using an automated diacetylmonoxamine method (Technicon Industrial Method 339-01, Technicon Industries, Tarrytown, NY). Plasma progesterone concentrations were analyzed in samples collected at 22 and $24 \mathrm{~h}$ of the infusion periods in a single validated radioimmunoassay (Elrod and Butler, 1993). The intraassay coefficient of variation for the progesterone assay was $11 \%$.

Uterine luminal $\mathrm{pH}$ was measured every $6 \mathrm{~h}$ during the treatment period. An adhesive EKG electrode was fixed to a shaved area of skin on the rump of each cow as the $\mathrm{pH}$ reference electrode. A micro $\mathrm{pH}$ electrode (MI-508 Esophageal pH electrode, Microelectrode Inc., Bedford, NH) attached to a Fisher Accumet $\mathrm{pH}$ meter (model 630) was used to measure uterine luminal $\mathrm{pH}$. The $\mathrm{pH}$ electrode was standardized by covering the tip of the $\mathrm{pH}$ electrode in a gauze pad soaked in a $\mathrm{pH} 7$ standard buffer and holding the $\mathrm{pH}$ electrode on the hide near, but not touching, the reference EKG electrode. A sheathed steel cannula (custom-made, $56-\mathrm{cm}$ long, 5-mm outside diameter) was inserted through the vaginal orifice. The cannula was pushed through the protective sheath before entering the cervical canal. Finally, the cannula was positioned approximately $8 \mathrm{~cm}$ beyond the uterine bifurcation in the horn ipsilateral to the corpus luteum (method developed in the preliminary trial described below). After rinsing with sterile saline, the micro $\mathrm{pH}$ electrode was then inserted through the cannula into the uterine lumen and extended $2.5 \mathrm{~cm}$ beyond the tip of the cannula. After a brief equilibration period, the $\mathrm{pH}$ reading stabilized and was recorded. The cannula and electrode were then gently retracted from the uterus and disinfected before each subsequent use. The electrode was standardized for each cow prior to each $\mathrm{pH}$ measurement.

Uterine lavage samples were collected after the 24and 48-h pH measurements. The micro $\mathrm{pH}$ electrode was withdrawn from the steel cannula. Sterile saline $(30 \mathrm{~mL})$ was flushed into the uterine lumen and immediately aspirated back through the cannula. Recovery for the uterine lavages varied from 2 to $9 \mathrm{~mL}$. A proteinase inhibitor, phenylmethylsulfonyl fluoride $(0.5 \%$ in ethanol; wt/vol), was added to the lavage samples to a final concentration of $0.005 \%$. The prostaglandin $\mathrm{E}_{2}\left(\mathbf{P G E}_{\mathbf{2}}\right)$ and $\mathrm{PGF}_{2 \alpha}$ content of the lavage samples were evaluated by ELISA $\left(\mathrm{PGE}_{2}\right.$ ELISA kit EA 02 and $\mathrm{PGF}_{2 \alpha}$ ELISA kit EA 05, Oxford Biomedical Research Inc., Oxford, MI). Each prostaglandin was measured in a single assay according to the protocol provided by the 

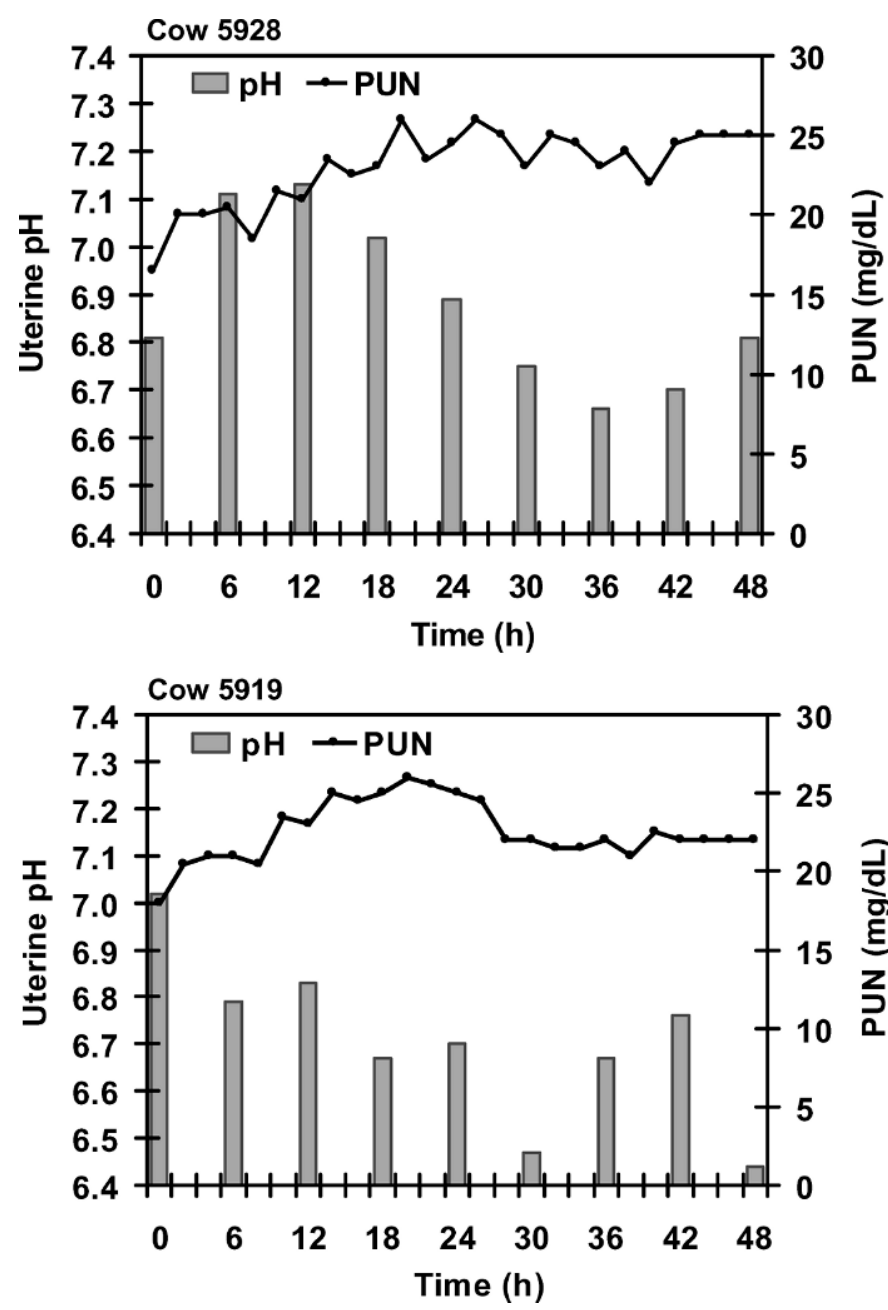

Figure 1. Plasma urea nitrogen (PUN) concentrations and uterine $\mathrm{pH}$ values of 2 cows (5928 and 5919) during the preliminary study.

supplier. In each system, serial dilutions of uterine lavage yielded inhibition lines that were parallel with the standard. Intraassay coefficients of variation among sample replicates were 5.9 and $5.8 \%$ for $\mathrm{PGF}_{2 \alpha}$ and $\mathrm{PGE}_{2}$, respectively. Total protein content of the lavage samples was measured by a phenol reagent method for biological fluids (micro protein determination procedure no. 690, Sigma Diagnostics, St. Louis, MO). The $\mathrm{PGF}_{2 \alpha}$ and $\mathrm{PGE}_{2}$ concentrations were reported per microgram of uterine lavage protein to account for variable dilution and recovery of the uterine fluid in lavages.

\section{Statistical Analysis for Experimental Study}

Data were analyzed using the mixed model procedure of SAS (SAS Inst., Inc., Cary, NC). The main effect of treatment and the interaction of treatment $\times$ time were tested using treatment by cow nested within group as the error term, where group represented the order in which treatments were administered. When the effect of treatment or treatment $\times$ time was significant, means separation procedures were carried out using the Tukey procedure of SAS. Data are presented as least square means and standard errors of the least square means.

\section{Preliminary Study}

Before the experimental study, additional dairy cows $(\mathrm{n}=8)$ were used in a preliminary study to establish the feasibility of repetitive uterine $\mathrm{pH}$ measurements over time. Stability and reliability of uterine $\mathrm{pH}$ measurements taken with an indwelling uterine Foley catheter (Elrod and Butler, 1993) were compared with those using a metal cannula. Estrus synchronization, blood sampling, and other management conditions were similar to the experimental study, except that cows were fed twice daily and no intravenous infusions were made. Cows were held without feed for $6 \mathrm{~h}$ and then fed 30 min before the first measurements at $0 \mathrm{~h}$, and fed every $12 \mathrm{~h}$ after that.

The PUN profiles of 2 cows, with uterine $\mathrm{pH}$ measurements every $6 \mathrm{~h}$ are shown in Figure 1. Uterine $\mathrm{pH}$ was depressed when PUN was elevated. The metal cannula approach provided more consistent $\mathrm{pH}$ recordings after $24 \mathrm{~h}$ compared with the Foley catheter. Therefore, this technique was adopted for the experimental study.

\section{RESULTS}

\section{Experimental Study}

Uterine $\mathrm{pH}$ before infusion was similar for the salineand urea-infused cows. At $24 \mathrm{~h}$, cows were switched immediately from saline to urea or from urea to saline infusion. There was no significant effect of treatment sequence on $\mathrm{PUN}$, uterine $\mathrm{pH}$, or uterine lavage concentrations of prostaglandin. Plasma urea nitrogen increased or decreased rapidly following initiation or termination of urea infusion. Therefore, treatment sequence was ignored in subsequent analyses.

Because cows were immediately switched from one treatment to the other at $24 \mathrm{~h}$, no $0 \mathrm{~h}$ measurements for the second infusion period were collected. Therefore, data are presented at $6,12,18$, and $24 \mathrm{~h}$ of infusion. Mean PUN concentrations for saline- and urea-infused cows are shown in Figures 2 and 3, respectively. Infusion of urea increased PUN $(P<0.001)$ relative to control treatment $(22.6 \pm 1.3$ vs. $16.6 \pm 1.3 \mathrm{mg} / \mathrm{dL}$ for urea and saline infusion, respectively). A treatment $\times$ time interaction $(P<0.05)$ was detected for uterine $\mathrm{pH}$. Uterine $\mathrm{pH}$ in control cows was neutral or higher and did not significantly change during the infusion period (Figure 2). 
Saline treatment

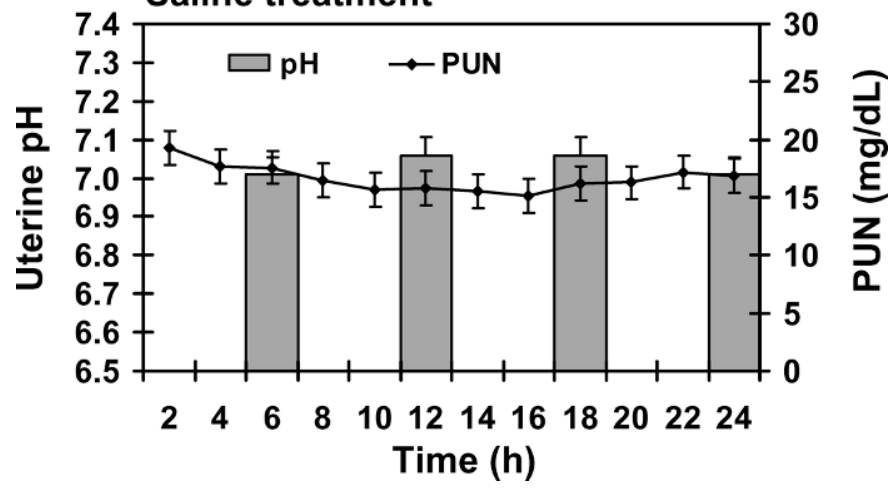

Figure 2. Least square means and standard errors for plasma urea nitrogen (PUN) concentrations and uterine $\mathrm{pH}$ during intravenous infusion of saline in lactating dairy cows $(\mathrm{n}=8)$. Uterine $\mathrm{pH}$ was not significantly affected by saline infusion.

In contrast, the uterine $\mathrm{pH}$ of urea-infused cows was similar at 6 and $12 \mathrm{~h}$, but decreased to acidic levels by $18 \mathrm{~h}(P<0.05)$, and tended $(P=0.09)$ to remain at that level through $24 \mathrm{~h}$ (Figure 3). Individual cows showed dynamic changes in uterine $\mathrm{pH}$ in response to PUN during the 48-h treatment period (Figure 4). The uterine $\mathrm{pH}$ of cow 6327 decreased during the urea treatment period, reached a nadir at the $36-\mathrm{h}$ measurement, and remained stable thereafter despite a continued rise in PUN through $48 \mathrm{~h}$. Likewise, the uterine $\mathrm{pH}$ of cow 6350 was low during urea infusion and increased with declining PUN concentrations after being switched from urea to saline infusion.

Plasma progesterone concentrations at 22 and $24 \mathrm{~h}$ of the infusion periods averaged $4.2 \pm 0.2$ and $4.4 \pm 0.2$

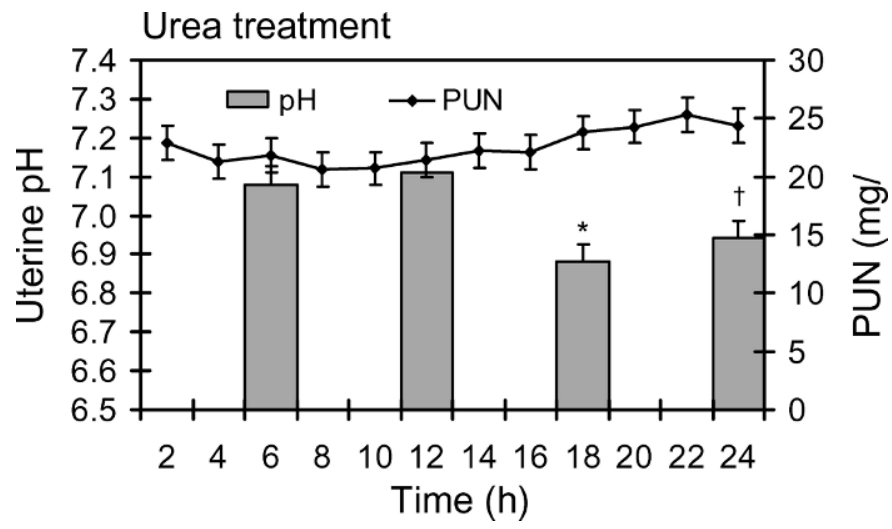

Figure 3. Least square means and standard errors for plasma urea nitrogen (PUN) concentrations and uterine $\mathrm{pH}$ during intravenous infusion of urea in lactating dairy cows $(n=8)$. A treatment $\times$ time interaction was detected for uterine $\mathrm{pH}$. *Uterine $\mathrm{pH}$ at $18 \mathrm{~h}$ differed $(P<0.05)$ from that at 6 and $12 \mathrm{~h}$. 'Uterine $\mathrm{pH}$ at $24 \mathrm{~h}$ tended $(P=$ $0.09)$ to differ from that at $12 \mathrm{~h}$.
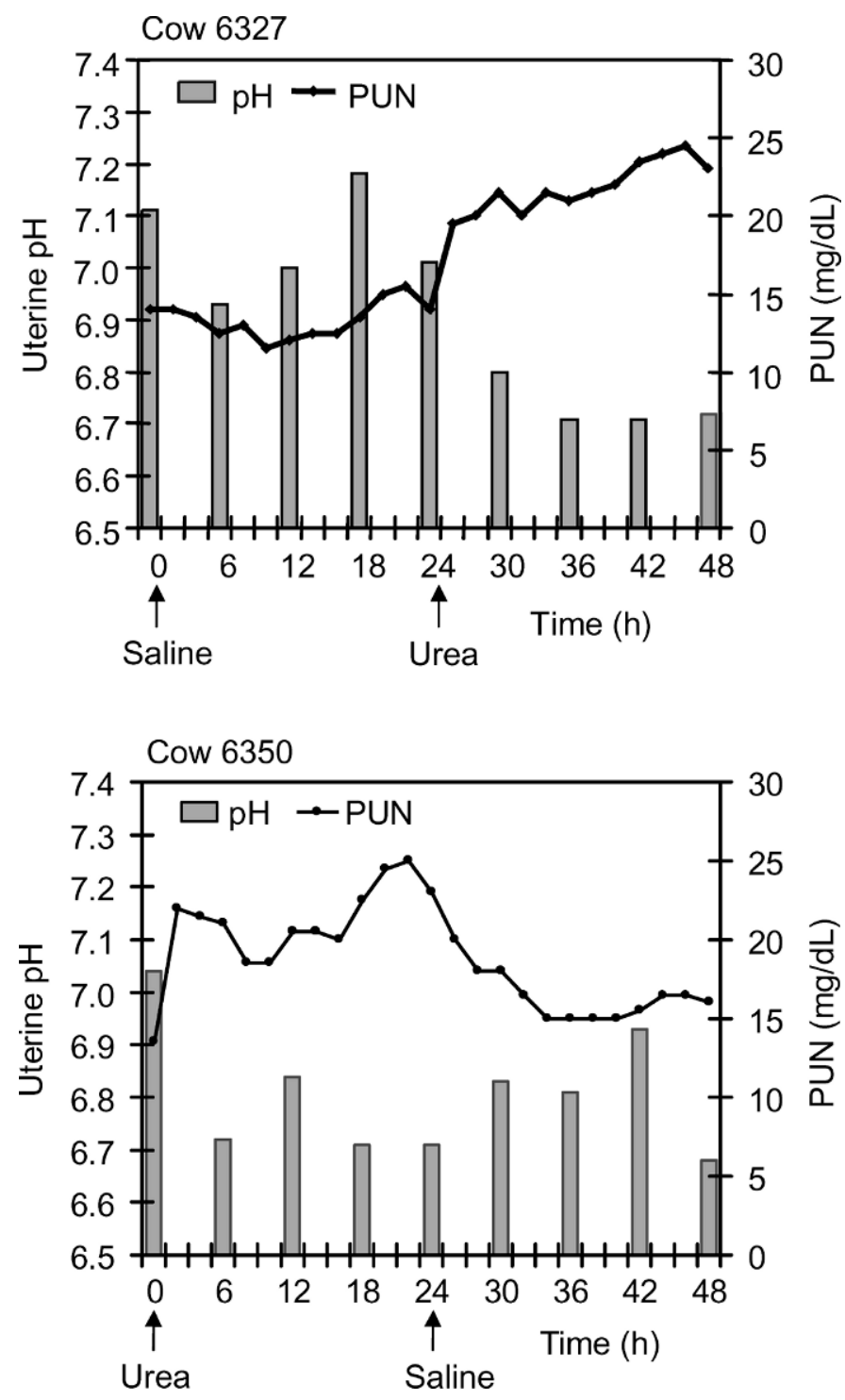

Figure 4. Plasma urea nitrogen (PUN) concentrations and uterine $\mathrm{pH}$ values from 2 cows (6327 and 6350) during intravenous infusion of saline and urea. Cow 6327 was infused with saline $(0$ to $24 \mathrm{~h})$ followed by urea ( 24 to $48 \mathrm{~h}$ ). Cow 6350 was infused with urea ( 0 to $24 \mathrm{~h}$ ) followed by saline ( 24 to $48 \mathrm{~h}$ ).

$\mathrm{ng} / \mathrm{mL}$, respectively, and were not affected by treatment $(P>0.05)$. Concentrations of $\mathrm{PGF}_{2 \alpha}(3.38 \pm 1.49 \mathrm{pg} / \mu \mathrm{g}$ of protein) and $\mathrm{PGE}_{2}(1.95 \pm 0.63 \mathrm{pg} / \mu \mathrm{g}$ of protein $)$ in uterine lavage samples did not differ between treatments $(P>0.10)$. The ratio of $\mathrm{PGF}_{2 \alpha}$ to $\mathrm{PGE}_{2}$ was similar $(0.83 \pm 0.18, P>0.10)$.

\section{DISCUSSION}

Effects of PUN on conception rate of dairy cows have been studied. Most (Blanchard et al., 1990; Canfield et al., 1990; Elrod and Butler, 1993; Ferguson et al., 1993; 
Butler et al., 1996), but not all (Howard et al., 1987; Carroll et al., 1988; Barton et al., 1996), studies have concluded that high PUN concentrations are associated with decreased fertility. The present study demonstrated that increasing PUN by intravenous infusion of urea reduces uterine luminal $\mathrm{pH}$ in lactating cows during the luteal phase of the estrous cycle. These results support those of previous reports for cows (Elrod et al., 1993) and heifers (Elrod and Butler, 1993), in which uterine luminal $\mathrm{pH}$ increased from estrus to $\mathrm{d} 7$ in control cows, but remained low during the luteal phase in cows fed a high protein diet. Smith et al. (2000) infused urea for 2 -h periods, increasing PUN in heifers, and found that uterine $\mathrm{pH}$ decreased in response to elevated PUN. Collectively, these studies provide strong evidence that PUN concentrations in lactating cows and heifers directly alter uterine $\mathrm{pH}$.

Timing of the observed changes in uterine luminal $\mathrm{pH}$ in response to elevated PUN may be critical for understanding the effects of PUN on embryo survival. Elrod and Butler (1993) suggested that the decrease in uterine luminal $\mathrm{pH}$ during the luteal phase might reflect changes in uterine secretory activity in response to urea. Variations in the uterine environment caused by high PUN concentrations may therefore create a hostile or suboptimal environment for early embryo development. The interaction between diet-related increases in PUN and the inductive effects of progesterone on uterine luminal secretions, as well as other mechanisms for reproductive failure were previously reviewed (Butler, 1998; Westwood et al., 1998).

Uterine luminal $\mathrm{pH}$ is controlled by carbonic anhydrase (CA), which catalyzes the reversible reaction: $\mathrm{H}_{2} \mathrm{O}+\mathrm{CO}_{2} \leftrightarrow \mathrm{H}_{2} \mathrm{CO}_{3} \leftrightarrow \mathrm{H}^{+}+{ }^{-} \mathrm{HCO}_{3}$. This enzyme is present in many secretory epithelia including the reproductive tract (Rodriguez-Martinez et al., 1991), and functions in the selective transport of hydrogen and bicarbonate ions (Swenson, 1991). Depending on the permeability of apical vs. basolateral plasmalemmae, epithelial cells can export $\mathrm{H}^{+}$or $\mathrm{HCO}_{3}$ apically or basally in exchange for sodium, potassium, and chloride ions to affect cellular ion content and to modify the $\mathrm{pH}$ of the luminal fluid (Rodriguez-Martinez et al., 1991). Unique isozymes of CA are induced by progesterone in the human or rabbit uterus (Hodgen and Falk, 1971; Falk and Hodgen, 1972) and, therefore, abundance varies by stage of cycle. In preliminary unpublished studies, uterine endometrial biopsies were collected from lactating cows and CA increased between estrus and $\mathrm{d}$ 9 of the estrous cycle $(4.6 \pm 0.4$ and $6.1 \pm 0.5$ units $/ \mathrm{mg}$ of protein, respectively; $P=0.02 ; \mathrm{n}=13$ ). The apparent steroid-dependency of CA is particularly intriguing because the observed changes in uterine $\mathrm{pH}$ in association with PUN occurred only during the luteal phase (Elrod and Butler, 1993; Elrod et al., 1993). Conceivably, high urea could alter uterine $\mathrm{pH}$ by changing $\mathrm{CA}$ activity during the luteal phase, but not at estrus.

Studies have addressed the effects of high PUN concentrations on early embryo development. Blanchard et al. (1990) found no differences in the average number of fertilized, unfertilized, transferable, or nontransferable ova collected from lactating cows fed 73 or $64 \%$ rumen-degradable intake protein. A greater percentage of fertilized ova were recovered, however, from cows fed less rumen-degradable intake protein. Cows fed smaller amounts of rumen-degradable intake protein also tended to have a higher mean percentage of transferable embryos. A higher percentage of cows fed greater amounts of rumen-degradable intake protein failed to yield transferable embryos. In a related experiment, we found that embryos from donor cows having elevated PUN concentrations were less likely to survive after transfer to recipient heifers than embryos from cows having moderate PUN concentrations (Bode et al., 2001). Taken together, these studies indicate that high PUN concentrations may affect oocyte health, embryo survival, or both.

Decreased uterine $\mathrm{pH}$ observed in the current study is a likely mechanism by which elevated PUN concentrations affect embryo survival. Culture of early bovine embryos at $\mathrm{pH}$ less than 7 reduced cleavage rates and development to the blastocyst stage (Ocon and Hansen, 2003). These in vitro results indicate that suboptimal uterine $\mathrm{pH}$ in response to high concentrations of PUN in vivo may inhibit early embryonic development.

In the current study, uterine $\mathrm{pH}$ during the luteal phase was consistently reduced after 6 to $12 \mathrm{~h}$ of elevated PUN resulting from intravenous urea infusion. Results from individual cows attest to the dynamic nature of uterine $\mathrm{pH}$ in response to increases or decreases in PUN. Uterine $\mathrm{pH}$ decreased in response to prolonged exposure to increased PUN, but quickly recovered when PUN decreased. Uterine $\mathrm{pH}$ often stabilized near the end of the urea infusion period despite further increases in PUN concentrations. The potential for adaptation to high concentrations of urea was suggested by Westwood et al. (1998) and merits further investigation.

Previous studies indicated an inverse relationship between PUN and progesterone concentrations during the luteal phase. Jordan and Swanson (1979) found that serum progesterone was lower on $\mathrm{d} 14$ after estrus when cows were fed 16.3 or $19.3 \%$ CP than when fed $12.7 \%$ CP. Sonderman and Larson (1989) reported reduced progesterone concentrations on d 12 after estrus in cows fed $20 \%$ protein compared with cows fed $14 \%$ protein. In the present study, an acute elevation of PUN around $\mathrm{d} 7$ after estrus did not affect plasma progester- 
one concentrations, in contrast to earlier reports in which high protein diets were fed for many days.

Studies conducted by Buford et al. (1996) and Seals et al. (1998) showed that cows treated with $\mathrm{PGF}_{2 \alpha} 5$ to 8 $\mathrm{d}$ after breeding had lower pregnancy rates than control cows, despite progesterone supplementation. Those authors suggested that $\mathrm{PGF}_{2 \alpha}$ or another product of the corpus luteum might contribute to embryonic loss. During the present study, concentrations of $\mathrm{PGF}_{2 \alpha}, \mathrm{PGE}_{2}$, or the ratio of $\mathrm{PGF}_{2 \alpha}$ to $\mathrm{PGE}_{2}$ in uterine lavage samples were not altered by treatment. Therefore, changes in uterine $\mathrm{pH}$ may be the primary mechanism through which fertility is affected in cows having high PUN concentrations. Changes in uterine $\mathrm{pH}$ may indicate or reflect additional changes in the uterine environment that impact fertility.

\section{CONCLUSIONS}

Feeding high levels of dietary protein is associated with decreased fertility in dairy cows. The results of this study suggest a potential mechanism through which PUN can affect the uterine environment and embryo survival. A decrease in uterine luminal $\mathrm{pH}$ occurred in response to urea infusion. The uterus, therefore, can acutely respond to circulating PUN. Further study is necessary to determine how a change in uterine $\mathrm{pH}$ may influence the fertility of dairy cows through effects on embryo development or viability.

\section{ACKNOWLEDGMENTS}

This study was supported by USDA NRICGP Grant 98-35203-6274. The technical support of S. Pelton and W. English is gratefully acknowledged.

\section{REFERENCES}

Barton, B. A., H. A. Rosario, G. W. Anderson, B. P. Grindle, and D. J. Carroll. 1996. Effects of dietary crude protein, breed, parity, and health status on the fertility of dairy cows. J. Dairy Sci. 79:2225-2236.

Blanchard, T., J. D. Ferguson, L. Love, T. Takeda, B. Henderson, J. Hasler, and W. Chalupa. 1990. Effect of dietary crude-protein type on fertilization and embryo quality in dairy cattle. Am. J. Vet. Res. 51:905-908.

Bode, M. L., R. O. Gilbert, and W. R. Butler. 2001. Effects of high plasma urea nitrogen levels on bovine embryo quality and development. J. Dairy Sci. 84(Suppl. 1):116. (Abstr.)

Buford, W. I., N. Ahmad, F. N. Schrick, R. L. Butcher, P. E. Lewis, and E. K. Inskeep. 1996. Embryotoxicity of a regressing corpus luteum in beef cows supplemented with progestogen. Biol. Reprod. 54:531-537.

Butler, W. R. 1998. Review: Effect of protein nutrition on ovarian and uterine physiology in dairy cattle. J. Dairy Sci. 81:2533-2539.
Butler, W. R., J. J. Calaman, and S. W. Beam. 1996. Plasma and milk urea nitrogen in relation to pregnancy rate in dairy cattle. J. Anim. Sci. 74:858-865.

Canfield, R. W., C. J. Sniffen, and W. R. Butler. 1990. Effects of excess degradable protein on postpartum reproduction and energy balance in dairy cattle. J. Dairy Sci. 73:2342-2349.

Carroll, D. J., B. A. Barton, G. W. Anderson, and R. D. Smith. 1988 Influence of protein intake and feeding strategy on reproductive performance of dairy cows. J. Dairy Sci. 71:3470-3481.

Elrod, C. C., and W. R. Butler. 1993. Reduction of fertility and alteration of uterine $\mathrm{pH}$ in heifers fed excess ruminally degradable protein. J. Anim. Sci. 71:694-701.

Elrod, C. C., M. Van Amburgh, and W. R. Butler. 1993. Alterations of $\mathrm{pH}$ in response to increased dietary protein in cattle are unique to the uterus. J. Anim. Sci. 71:702-706.

Falk, R. J., and G. D. Hodgen. 1972. Carbonic anhydrase isoenzymes in normal human endometrium and erythrocytes. Am. J. Obstet. Gynecol. 112:1047-1051.

Ferguson, J. D., T. Blanchard, D. T. Galligan, D. C. Hoshall, and W. Chalupa. 1988. Infertility in dairy cattle fed a high percentage of protein degradable in the rumen. J. Am. Vet. Med. Assoc. 192:659-662.

Ferguson, J. D., D. T. Galligan, T. Blanchard, and M. Reeves. 1993. Serum urea nitrogen and conception rate: The usefulness of test information. J. Dairy Sci. 76:3742-3746.

Hodgen, G. D., and R. J. Falk. 1971. Estrogen and progesterone regulation of carbonic anhydrase isoenzymes in guinea pig and rabbit uterus. Endocrinology 89:859-864.

Howard, H. J., E. P. Aalseth, G. D. Adams, L. J. Bush, R. W. McNew, and L. J. Dawson. 1987. Influence of dietary protein on reproductive performance of dairy cows. J. Dairy Sci. 70:1563-1571.

Jordan, E. R., T. E. Chapman, D. W. Holtan, and L. V. Swanson. 1983. Relationship of dietary crude protein to composition of uterine secretions and blood in high-producing postpartum dairy cows. J. Dairy Sci. 66:1854-1862.

Jordan, E. R., and L. V. Swanson. 1979. Serum progesterone and luteinizing hormone in dairy cattle fed varying levels of crude protein. J. Anim. Sci. 48:1154-1158.

Ocon, O. M., and P. J. Hansen. 2003. Disruption of bovine oocytes and preimplantation embryos by urea and acidic $\mathrm{pH}$. J. Dairy Sci. 86:1194-1200

Rajala-Schultz, P. J., W. J. A. Saville, G. S. Frazer, and T. E. Wittum. 2001. Association between milk urea nitrogen and fertility in Ohio dairy cows. J. Dairy Sci. 84:482-489.

Rodriguez-Martinez, H., E. Ekstedt, and Y. Ridderstrale. 1991. Histochemical localization of carbonic anhydrase in the female genitalia of pigs during the oestrous cycle. Acta Anat. 140:41-47.

Seals, R. C., J. W. Lemaster, F. M. Hopkins, and F. N. Schrick. 1998. Effects of elevated concentrations of prostaglandin F2 alpha on pregnancy rates in progestogen supplemented cattle. Prostaglandins Other Lipid Mediat. 56:377-389.

Smith, J. F., L. J. Hagemann, A. J. Peterson, S. Beaumont, M. Berg, M. Donnison, A. Ledgard, R. M. McDonald, and G. A. Verkerk. 2000. Effect of infusion of urea or ammonia to dairy heifers on the composition of follicular fluid and uterine secretions. Page 37 in Proc. 14th Int. Congr. Anim. Reprod., Stockholm, Sweden.

Sonderman, J. P., and L. L. Larson. 1989. Effect of dietary protein and exogenous gonadotropin-releasing hormone on circulating progesterone concentrations and performance of Holstein cows. J. Dairy Sci. 72:2179-2183.

Swenson, E. 1991. Distribution and functions of carbonic anhydrase in the gastrointestinal tract. Pages 265-288 in The Carbonic Anhydrases: Cellular Physiology and Molecular Genetics. S. J. Dodgson, R. E. Tashian, G. Gros, and N. D. Carter, eds. Plenum Press, New York, NY.

Westwood, C. T., I. J. Lean, and R. C. Kellaway. 1998. Indications and implications for testing of milk urea in dairy cattle: A quantitative review. Part 2. Effect of dietary protein on reproductive performance. N.Z. Vet. J. 46:123-130. 